\title{
The role of Borrelia burgdorferi infection in scleroderma
}

\section{Rola zakażenia Borrelia burgdorferi w rozwoju twardziny}

\author{
Żaneta Smoleńska, Anna Masiak, Adrian Strzelecki, Zbigniew Zdrojewski
}

Clinic of Internal Diseases, Connective Tissue Diseases and Geriatrics, Medical University of Gdansk

Key words: Borrelia burgdorferi, scleroderma, fibrosis.

Słowa kluczowe: Borrelia burgdorferi, twardzina, włóknienie.

\begin{abstract}
Sum mary
Borrelia burgdorferi, a Gram-negative, spiral-shaped bacterium transmitted to humans via tick bites, is the etiologic agent of borreliosis (Lyme disease) with diverse clinical manifestations. There are several types of pathological lesions in the course of Lyme disease: inflammatory, atrophic and sclerotic ones. Recent studies suggest a possible association between localized scleroderma, lichen sclerosus and Borrelia burgdorferi. A clinical similarity between late skin manifestation acrodermatitis chronica atrophicans, lichen sclerosis and morphea was noted. Studies showing regression of skin lesions in patients with localized scleroderma treated with targeted antibiotic therapy against Borrelia provide evidence for the role of the infection in the pathogenesis of morphea. The role of Borrelia burgdorferi infection in the complex pathogenesis of systemic scleroderma is still controversial. This article discusses the results of studies involving Borrelia infection in the pathogenesis of scleroderma and some dermatological disorders and describes various skin changes of borreliosis.
\end{abstract}

\section{Introduction}

Borrelia burgdorferi is a Gram-negative, spiral-shaped bacterium belonging to the Spirochaetaceae along with Leptospira and Treponema. The majority of pathogenic forms of these bacteria, forming approximately 12 species, are classified as the Borrelia burgdorferi sensu lato complex; it includes Borrelia burgdorferi sensu stricto, Borrelia garinii and Borrelia afzelii. All pathogenic strains are transmitted to humans by ticks, especially by Ixodes spp., and they are responsible for Lyme disease, a chronic, multi-system inflammatory disease the symptoms of which are the consequences of the direct action of

\section{Streszczenie}

Borrelia burgdorferi, bakteria Gram-ujemna o kształcie krętka, przenoszona na ludzi przez kleszcze, stanowi czynnik etiologiczny boreliozy (choroby z Lyme). Obraz kliniczny boreliozy jest bardzo zróżnicowany, a w jej przebiegu wyróżnia się kilka patomorfologicznych rodzajów zmian skórnych, takich jak zapalne, zanikowe i sklerotyczne. Badania naukowe w ostatnich dwudziestu latach wskazują na możliwy związek twardziny miejscowej i liszaja zanikowego z zakażeniem Borrelia burgdorferi. Wykazano, że istnieje kliniczne podobieństwo późnej zmiany skórnej w przebiegu boreliozy, tj. przewlekłego zanikowego zapalenia skóry, do liszaja zanikowego i morphea. Dowodu na udziat tej bakterii w etiopatogenezie twardziny miejscowej dostarczają wyniki badań, które wykazały cofanie się zmian skórnych po zastosowaniu celowanej antybiotykoterapii. Rola zakażenia Borrelia burgdorferi w złożonym patomechanizmie twardziny układowej jest wciąż kontrowersyjna. W artykule omówiono wyniki badań nad udziałem zakażenia Borrelia w etiopatogenezie twardziny i w wybranych chorobach dermatologicznych oraz różne objawy skórne spotykane w boreliozie.

the spirochete or its antigens, and cellular and humoral immune responses [1]. Borrelia burgdorferi sensu stricto is the main pathogen responsible for borreliosis (also known as Lyme disease, LD) in the US, whereas Borrelia afzelii and Borrelia garinii are responsible for the majority of cases in Europe [2].

In 1977 Steere et al. described cases of patients in the region of Lyme, Connecticut, with arthritis and skin lesions consistent with erythema chronicum migrans (ECM). At the beginning, they were thought to be cases of juvenile idiopathic arthritis. In this region humans were often bitten by ticks. In 1982 Burgdorfer isolated spiral-shaped

Address for correspondence:

Żaneta Smoleńska, PhD, Clinic of Internal Diseases, Connective Tissue Diseases and Geriatrics, Medical University of Gdansk, M. Skłodowskiej-Curie 3A, 80-210 Gdansk, e-mail: z.smolenska@wp.pl

Submitted: 30.07 .2014 
bacteria from the intestinal diverticula of these ticks, and in 1983 Steere et al. found a correlation between infection with these microorganisms and cases observed; finally, the spirochete Borrelia burgdorferi (named after the researcher mentioned above) was considered to be a direct etiological factor of LD [3].

In 1989 Steere [4] observed that B. burgdorferi "may cause an immune response that lasts for some time even if a microorganism has been killed". This statement started a discussion on the possibilities of persistent B. burgdorferi infection.

Being intracellular organisms, spirochetes may enter different tissues in humans and easily cross the bloodbrain barrier; therefore they are responsible for various neuropsychiatric symptoms as a result of infecting the central nervous system. A great amount of evidence indicates that $B$. burgdorferi is well adapted to avoid a reaction triggered by the host's immune system; therefore it is able to survive and remain infectious despite aggressive antibiotic therapy [5].

\section{Skin lesions in the course of borreliosis and in selected dermatological conditions associated with fibrosis}

According to a current classification, borreliosis is divided into early, localized, disseminated and late Lyme disease. Late Lyme disease is borreliosis present for more than 12 months.

The course of Lyme disease may be associated with various pathomorphological skin lesions that are in flammatory, atrophic or sclerotic. Dermal forms of Lyme disease include erythema migrans (EM) at the disease onset and subsequent lesions such as erythema chronicum migrans (ECM), borrelial lymphocytoma (BL) and acrodermatitis chronica atrophicans (ACA), a symptom that was described a long time before its etiological factor was discovered.

Erythema migrans usually develops 1-3 weeks after a tick bite at the site of the tick bite. It is an inflammatory reaction with a type 4 cell-mediated response background, consisting of groups of lymphocytes, dendritic cells, macrophages and plasma cells located around the blood vessels in the dermis. Contrary to typical bacterial infections there is a low number of neutrophils [6]. According to the literature it is present in $30-60 \%$ of people infected. A classical lesion has the form of erythema with well-defined borders, usually with central clearing or with a central papule of a purple-red color ("bull's eye"), with the minimum diameter of $5 \mathrm{~cm}$, although smaller eruptions are sometimes also observed. When untreated, EM regresses spontaneously within a month. When treated, this period is shorter. However, its elimination during antibiotic treatment does not always correspond to complete elimination of spirochete infection [7].

Atypical forms of erythema migrans include chronic erythema migrans (ECM), which is a single lesion persisting for many months on the skin, as well as multiple erythema migrans, which is associated with the presence of numerous disseminated erythematous spots in early disseminated Lyme disease.

Borrelial lymphocytoma, a pseudolymphoma, is a very rare skin lesion, representing up to $1 \%$ of all cases of early disseminated LD, and it develops mainly in children. This lesion is a result of abnormal proliferation of lymphocytes in response to a spirochete antigen. Polyclonal proliferation of B cells and plasma cells leads to the formation of infiltrations consisting mainly of these cells in the dermis. They have the form of small nodules of a red or purple-red color, and are located mainly on the skin of ear conchas, nape, mammilla and scrotum.

Acrodermatitis chronica atrophicans is a late skin symptom of Lyme disease, and it develops mainly in patients infected with Borrelia afzelii spirochetes. This bacterium is endemic to Europe, especially its north-central regions, so this complication is not observed in the US, except for cases in people who migrated from Europe. ACA develops within several years after a tick bite and is mainly observed among adult women. Most commonly lesions are located on the skin of distal extremities, but they might also appear on the face and trunk. A pathogenetic mechanism, not fully known yet, subsequently leads to further stages such as inflammatory-edematous, atrophic and, sometimes, scleroderma-like stages. Early inflammatory lesions are not characteristic and are often misdiagnosed. They have the form of purple-red, poorly demarcated discolorations accompanied by swollen subcutaneous tissue, especially in the area of the hands and feet, but they are most frequently observed on the lower extremities. A typical symptom in this disease phase is "acute blue finger", namely one finger or toe becomes cyanotic and swollen, and it may be mistakenly diagnosed as a secondary Raynaud's symptom. When appropriate antibiotic therapy has been introduced, in time inflammatory lesions are suppressed, and they completely regress. When untreated, these lesions lead to a second disease phase, namely an atrophic phase, when focal or widespread skin thickening may be additionally observed. In the atrophic period the skin within a lesion becomes significantly thinner, looks like absorbing paper, is shiny, and there are telangiectasia and hyper- and hypopigmentation. Usually it is also dry and itchy. More intensive reactions of the skin to touch and small traumas (allodynia) as well as the sensation of numbness and paresthesia at the site of the lesion are a result of peripheral polyneuropathy. In 
the late period of Lyme disease, skin lesions usually coexist with other symptoms associated with the nervous system such as cranial nerve inflammation, hearing impairment and chronic arthritis. Atrophic and sclerotic skin lesions similar to skin lesions observed in late LD are also present in two other dermatological conditions of an autoimmune background: localized scleroderma and lichen atrophicus. These conditions are of unknown etiology, and different infections are considered among other etiological factors [8].

Localized scleroderma (LS) is an inflammatory condition leading to thickening of the skin and subcutaneous tissue as a result of excessive production of collagen. This condition may have various forms, including linear scleroderma (lesions consistent with lines or streaks) and morphea (a rounded lesion). In the early disease phase the vascular endothelium in the skin becomes damaged and a local inflammatory reaction develops. According to the studies, including those performed in Polish centers, the early morphea phase is associated with elevated levels of interleukin $1 \beta$ (IL-1 $\beta$ ) in the serum of such patients and increased expression of genes for IL-1 $\beta, I L-23$ and IL-17A in polymorphonuclear blood cells $[9,10]$. In the late phase fibroblast proliferation stimulated mainly by IL-1 $\beta$ can be observed, and it leads to fibrosis. In the majority of patients with localized scleroderma, skin is damaged on the trunk or on the extremities on one side. Lesions may be red or purple and are usually well demarcated. Sometimes, skin lesions may appear white or wax-like. Localized scleroderma has to be differentiated from systemic sclerosis (SSc) based on the lack of evidence for internal organ involvement.

Lichen atrophicus or sclerosus is a condition characterized by the presence of white discolorations of the skin that are usually present on the neck, nape, genital organs and in surrounding areas. In the early disease stage histopathological findings of skin specimens reveal swelling of collagen fibers, perivascular lymphocytic infiltrations and deposits of IgG, IgA and IgM immunoglobulins, complement and fibrin, and in a later stage atrophy of elastic fibers can be observed. Scarring lesions and significant skin thinning can also be observed in this condition.

\section{Correlation between Borrelia burgdorferi and localized scleroderma and lichen atrophicus}

Within the last 20 years there have been reports on a possible correlation between localized scleroderma and lichen atrophicus and B. burgdorferi infection.

In 1985 Aberer [11] was the first to note a correlation between $B$. burgdorferi infection and development of localized scleroderma. She demonstrated that in 12\% (6 out of 50) patients with LD with skin lesions similar to ACA there was clinical similarity with lichen atrophicus and morphea [11]. Subsequent papers have demonstrated that some skin lesions associated with ACA are also histologically similar to lesions consistent with morphea $[2,12]$. Despite many similarities there are also visible differences between these dermal conditions. Acrodermatitis chronica atrophicans is mainly evident on the extensor surfaces of extremities, and at the beginning there is only red-purple swelling present for years, leading to atrophy of the epidermis and skin, and their sclerotization, especially above bone prominences. On the other hand, morphea does not exhibit any tendency with regard to lesion location, although it usually develops on the trunk and extremities and has the form of central skin thickening. A histopathological skin examination in late ACA demonstrates epidermal atrophy, and it is usually not observed in morphea.

Despite the fact that many studies did not confirm the presence of $B$. burgdorferi in skin lesions associated with localized scleroderma [13], there are reports where $B$. burgdorferi was directly isolated from eruptions related to scleroderma using immunohistochemistry and PCR $[12,14]$. The results of studies indicating clinical improvement with regard to skin lesions following antibiotic therapy provide strong evidence supporting the contribution of Borrelia sp. infection to lesions in scleroderma.

Breier et al. [2] isolated Borrelia afzelii from skin lesions in a patient with localized scleroderma who also exhibited high levels of anti-B. burgdorferi lgG in the serum. It is worth emphasizing that researchers observed reduced levels of specific antibodies and partial suppression of skin fibrosis following antibiotic therapy with $\beta$-lactams.

Epidemiological studies have provided interesting data that enable better understanding of results of studies on a potential correlation between LD and dermatological conditions described above.

Population differences associated with Borrelia infection and Lyme disease morbidity rate should be taken into account when the results of such studies are interpreted. Population differences with regard to the correlation between $B$. burgdorferi and morphea have been demonstrated. This correlation was confirmed in Japanese and European populations, as well as in a Brazilian population from the Amazon River basin, but not in patients from North America [15]. In a population of patients with morphea in the northern US B. burgdorferi DNA was not detected [12]. Conflicting results were obtained for different geographical regions in Europe with regard to positive results for $B$. burgdorferi in a group 
of patients with morphea and lichen sclerosus [8, 12, $16,17]$. Positive results were observed in patients from Austria, Switzerland, Germany, Italy and Japan, whereas negative results were observed in populations from Denmark, France, Holland, Spain and Finland [8, 12, 18]. Such conflicting results may be a result of differences in the incidence of Borrelia strains in Europe and the USA. Borrelia burgdorferi sensu stricto is the predominant strain in the northern US, and a correlation between this strain and late dermatological symptoms of LD has never been documented [19]. Additionally, in many regions of Europe various clinical forms of LD have been discovered, and they are associated with various strains of $B$. burgdorferi [20]. It has to be additionally emphasized that a genetic background is of significant importance for an immune response to $B$. burgdorferi infection. Based on study results presented, it has been suggested that a population of Central Europe may exhibit a genetic predisposition for development of skin lesions associated with fibrosis during infection with $B$. burgdorferi $[16,20]$.

In 2009, American researchers published a paper suggesting a correlation between Borrelia infection and rapid development of autoimmune processes leading to the development of morphea-like changes in a population of children and adolescents, and it is confirmed by higher serum levels of antinuclear antibodies (ANA) in this population of patients [21].

Despite intensive studies there is still no firm evidence to indicate a relation between $B$. burgdorferi infection and development of some dermatological conditions with a component of fibrosis.

Scientific evidence collected within the last years by Polish scientists refutes the hypothesis that Borrelia infection is an etiological factor in the pathogenesis of scleroderma. In a group of 110 patients with chronic Lyme disease in north-east Poland where people are at a high risk of tick bites, no skin lesions typical of morphea or other scleroderma-like skin lesions have been observed [22]. However, it has to be emphasized that these patients have been previously treated with antibiotics, some of them even several times due to recurrent infection or resistance. Taking into account previous results of studies indicating that antibiotic therapy may be beneficial for scleroderma, it cannot be excluded that antibiotic therapy was the factor that affected the whole clinical picture in these patients. However, coexistence of Borrelia infection and morphea is more likely to be a result of secondary infection, or it may be a result of a direct influence of a given bacterial strain depending on geographical variability. A correlation between localized scleroderma and lichen atrophicus and infection with the $B$. burgdorferi spirochete is still a topic of hot discussion, and further studies are necessary. The diagnostic method to detect spirochetes directly and its specificity depending on disease stage is also controversial.

\section{Borrelia burgdorferi and metabolism of connective tissue}

With regard to the possible pathogenesis of skin lesions in the course of LD and the possible involvement of infection with these bacteria in other skin lesions with a component of fibrosis, attention should be paid to the high affinity of Borrelia burgdorferi to collagen and elastic fibers that has been observed in histopathological skin lesions in patients with LD [19]. Above all, it should be noted that Borrelia burgdorferi has developed many adaptive features facilitating penetration of the human body by bacteria, especially in the musculoskeletal system [5]. There is evidence that the presence of decorin in the ligaments and tendons plays a vital role in bacterial invasion. It was demonstrated that mice with a deficiency of this enzyme were resistant to infection with Borrelia burgdorferi. Decorin is a proteoglycan located intracellularly or in the intercellular matrix. It is a connective tissue component, binding to type I and II collagen fibers and playing a role in the formation of the extracellular matrix structure. It has been hypothesized that when a spirochete binds to decorin, its binding to collagen becomes impossible, thus leading to collagen destruction [19].

\section{Infection with Borrelia burgdorferi with regard to the search for an etiological factor of systemic sclerosis}

Taking into account the etiological correlation between $B$. burgdorferi and skin fibrosis consistent with localized scleroderma and its different forms presented above, there arises the question whether the same correlation can be found for systemic sclerosis.

The pathomechanism of this condition is thought to be complex and its etiology multifactorial, including disturbed collagen production by fibroblasts as well as vascular lesions that together may affect the development of sclerosis. The endothelial damage is the first step in its pathogenesis, and it may manifest with a Raynaud's symptom and microangiopathy. Genetic, environmental and infectious factors may play a role in the pathomechanism of this condition [23]. Persistent infection with $B$. burgdorferi is thought to affect the cells of the vascular endothelium, and it may lead to their damage, as well as to the development of microvasculopathy and/or activation of skin fibroblasts [23].

Wackernagel et al. [24] described a patient with sclerosis in whom this condition developed only after 
infection with B. burgdorferi. Results of diagnostic tests confirming the infection included positive results for antibodies against $B$. burgdorferi and positive PCR for $B$. burgdorferi in the urine. The patient exhibited a Raynaud's symptom, pitting swelling of the face and upper trunk that led to skin thickening and sclerosis. Additional serological tests revealed positive anti-centromere antibodies. The role of a bacterial infection as a pathological factor was confirmed after treatment had been applied. The infection was successfully treated with intravenous ceftriaxone, and complete regression of skin lesions was observed. This case report suggests that $B$. burgdorferi may be treated as an etiological factor causing systemic sclerosis in patients with a predisposition for its development [24].

However, some studies did not confirm the theory claiming that bacterial infections play a role in the complex pathomechanism of this condition. Mayes et al. [23] used a broad bacterial panel evaluating the genetic presence of several bacterial species, including B. burgdorferi, and they did not demonstrate persistent bacterial infections in skin biopsy specimens collected from patients with sclerosis.

The role of infection with $B$. burgdorferi or other bacterial infections as a causative factor participating in the complex pathomechanism of systemic sclerosis is controversial.

Some studies suggest that viral infections may play a role in the pathogenesis of this systemic connective tissue disease. The infection with human cytomegalovirus that infects endothelial cells and monocytes is suspected to play a role in the development of SSc [25]. Researchers suggest that cytomegalovirus infection leads to endothelial damage and impaired fibroblast functions. Parvovirus B19 may also play a vital role, among other viral factors. DNA of this virus was demonstrated more often in skin biopsy specimens and bone marrow specimens in patients with SSc compared to a control group [26].

Available methods to treat SSc are only partially effective, and therefore it is necessary to conduct further studies regarding the pathomechanism of this condition, including the role of persistent infection in the SSC pathogenesis.

\section{Summary}

The role of Borrelia burgdorferi infection is still poorly known with regard to its possible role as an etiological factor in the development and pathogenesis of some dermatological and rheumatological conditions, including sclerosis. The problem of bacterial contribution to the development of many late organ lesions in the course of
LD is still an issue that has to be explored further. Therefore the subject of studies regarding the Borrelia sp. spirochete requires further attention and interest.

The authors declare no conflict of interest.

\section{References}

1. Parada-Turska J. Stawowa postać boreliozy - obraz kliniczny i leczenie. Reumatologia 2013; 51: 51-55.

2. Breier FH, Aberer E, Stanek G, et al. Isolation of Borrelia afzelii from circumscribed scleroderma. Br J Dermatol 1999; 140: 925-930.

3. Barbour AG, Burgdorfer W, Grunwaldt E, Steere AC. Antibodies of patients with Lyme disease to components of the Ixodes dammini spirochete. J Clin Invest 1983; 72: 504-515.

4. Steere AC. Lyme disease. N Engl J Med 1989; 321: 586-596.

5. Berndtson K. Review of evidence for immune evasion and persistent infection in Lyme disease. Int J Gen Med 2013; 6: 291-306.

6. Moniuszko A, Penza P, Czupryna P, et al. The role of dendritic cells in the pathogenesis of Lyme disease. Centr Eur J Immunol 2013; 38: 569-577.

7. Flisiak R, Pancewicz S. Diagnostyka i leczenie boreliozy z Lyme rekomendacje Polskiego Towarzystwa Epidemiologów i Lekarzy Chorób Zakaźnych. Przegl Epidemiol 2008; 62: 193-199.

8. Ozkan S, Atabey N, Fetil E, et al. Evidence for Borrelia burgdorferi in morphea and lichen sclerosus. Int J Dermatol 2000; 39: 278-283.

9. Dańczak-Pazdrowska A, Kowalczyk MJ, Szramka-Pawlak B, et al. Interleukin $1 \beta$ in morphea. Centr Eur J Immunol 2012; 37 : 247-252.

10. Dańczak-Pazdrowska A, Kowalczyk M, Szramka-Pawlak B, et al. Interleukin-17A and interleukin-23 in morphea. Arch Med Sci 2012; 8: 1089-1095.

11. Aberer E, Klade H, Hobisch G. A clinical, histological, and immunohistochemical comparison of acrodermatitis chronica atrophicans and morphea. Am J Dermatopathol 1991; 13: 334-341.

12. Weide B, Walz T, Garbe C. Is morphoea caused by Borrelia burgdorferi? A review. Br J Dermatol 2000; 142: 636-644.

13. Trevisan G, Rees DH, Stinco G. Borrelia-burgdorferi and localized scleroderma. Clin Dermatol 1994; 12: 475-479.

14. Fujiwara H, Fujiwara K, Hashimoto K, et al. Detection of Borrelia burgdorferi DNA (B garinii, or B afzelii) in morphea and lichen sclerosus et atrophicus tissues of German and Japanese but not of US patients. Arch Dermatol 1997; 133: 41-44.

15. Eisendle K, Grabner T, Zelger B. Morphoea: a manifestation of infection with Borrelia species? Br J Dermatol 2007; 157 : 1189-1198.

16. Wienecke R, Schlüpen EM, Zöchling N, et al. No evidence for Borrelia burgdorferi-specific DNA in lesions of localized scleroderma. J Invest Dermatol 1995; 104: 23-26.

17. Liang FT, Aberer E, Cinco $M$, et al. Antigenic conservation of an immunodominant invariable region of the VIsE lipoprotein among European pathogenic genospecies of Borrelia burgdorferi sp. J Infect Dis 2000; 182: 1455-1462. 
18. Moreno C, Kutzner H, Palmedo G, et al. Interstitial granulomatous dermatitis with histiocytic pseudorosettes: a new histopathologic pattern in cutaneous borreliosis. Detection of Borrelia burgdorferi DNA sequences by a highly sensitive PCR-ELISA. J Am Acad Dermatol 2003; 48: 376-384.

19. Müller KE. Damage of collagen and elastic fibres by Borrelia burgdorferi - known and new clinical and histopathological aspects. Open Neurol J 2012; 6: 179-186.

20. Schempp C, Bocklage $H$, Lange R, et al. Further evidence for Borrelia-burgdorferi infection in morphea and lichen sclerosus et atrophicus confirmed by DNA amplification. J Invest Dermatol 1993; 100: 717-720.

21. Prinz JC, Kutasi Z, Weisenseel P, et al. "Borrelia-associated early-onset morphea": a particular type of scleroderma in childhood and adolescence with high titer antinuclear antibodies? Results of a cohort analysis and presentation of three cases. J Am Acad Dermatol 2009; 60: 248-255.

22. Moniuszko A, Gińdzieńska-Sieśkiewicz E, Pancewicz SA, et al. Evaluation of skin thickness lesions in patients with Lyme disease measured by modified Rodnan total skin score. Rheumatol Int 2012; 32: 3189-3191.

23. Mayes MD, Whittum-Hudson JA, Oszust C, et al. Lack of evidence for bacterial infections in skin in patients with systemic sclerosis. Am J Med Sci 2009; 337: 233-235.

24. Wackernagel A, Bergmann AR, Aberer E. Acute exacerbation of systemic scleroderma in Borrelia burgdorferi infection. J Eur Acad Dermatol Venerol 2005; 19: 93-96.

25. Ferri C, Cazzato M, Giuggioli D, et al. Systemic sclerosis following human cytomegalovirus infection. Ann Rheum Dis 2002; 61: 937-938.

26. Zakrzewska K, Corcioli F, Carlsen KM, et al. Human parvovirus B19 (B19V) infection in systemic sclerosis patients. Intervirology 2009; 52: 279-282. 